Available online at GSC Online Press Directory

GSC Biological and Pharmaceutical Sciences

e-ISSN: 2581-3250, CODEN (USA): GBPSC2

Journal homepage: https://www.gsconlinepress.com/journals/gscbps

(RESEARCH ARTICLE)

\title{
Antineoplastic property of Ashwagandha for Paclitaxel concomitant, can induce p53- mediated apoptosis: In vitro search for anti-proliferative phytogent
}

\author{
Gopinath Rana * and Rajesh Juneja \\ Cellular and Molecular Therapeutics Laboratory, Venkatesh Natural Extract Pvt. Ltd., Chhindwara, Madhya Pradesh, \\ India.
}

Publication history: Received on 28 September 2020; revised on 05 October 2020; accepted on 08 October 2020

Article DOI: https://doi.org/10.30574/gscbps.2020.13.1.0317

\begin{abstract}
Ashwagandha (Withania somnifera L. Dunal) is an important and traditional medicinal herb found in India. It has been reported that, Ashwagandha has potential anti-proliferative as well as chemo-accelerative activity. The goal of this study was to investigate the most probable reason behind Ashwagandha's anti-proliferative and chemo-accelerative activity. In addition, chromatographically isolate and chemically characterize some new compound which have antineoplastic property and find the mode of action of it. In vitro assays (MTT and Western blot) for anti-tumorigenic potentiality of the isolated drug were carried out on HT-29, KB and HeLa cell lines. In this experimental study, purification and chemical characterization (by UV, FT-IR, HPLC, LC-MS, ${ }^{1} \mathrm{H}-\mathrm{NMR}$ ) of an anti-cancer drug has been found as Paclitaxel. MTT-assay shows an average $\mathrm{IC}_{50}$ value of the isolated Paclitaxel is $10 \mathrm{nM}$. Western blot data reveals there may be ROSassociated p53-MDM2-related cell proliferation and apoptosis by the drug's in vitro effect.
\end{abstract}

Keywords: Paclitaxel; Ashwagandha; ${ }^{1} \mathrm{H}-\mathrm{NMR}$; MTT assay; Western blot

\section{Introduction}

Several attempts have been launched to investigate the reasons and chemical components behind the anti-tumorigenic and chemo-accelerative activity of Ashwagandha (Withania somnifera L. Dunal) in phytotherapy [1]. A number of withanolieds, alkaloids of Withania somnifera L. Dunal, have been arrested and characterized as phyto-pharmacological agents against numerous human diseases from the ancient Ayurvedic era of India [2]. Withanolides have reported as immunomodulatory, neuroprotective and most importantly anti-proliferative phytochemicals against different types of cancer cells, neuroblastomas as well as myeloid cells [3]. It has been reported that chemotherapeutic efficiency of Paclitaxel in combination with Withania somnifera L. Dunal extract (methanol or water) enhances the anti-tumorigenic activity [4].

Cancer has now become a worldwide life threatening disease for its uncontrolled proliferative activity. This abnormal replication and invasion can attack any part of the human body like; brain, lung, stomach, pancreas, breast, prostate, cervix and so on [5]. Some forms of cancer are curable, and some are not but are under the lances of research. Recent trends in cancer diagnosis depends on chemotherapy, radiation and targeted therapy but those have side effects. It has been proved by recent scientists that phytochemicals are safe for mankind [6]. So in this bio-age, phytogents are also being introduced against malignancy [7-10]. Such a renowned big-brother among all antineoplastic agents is Paclitaxel (Taxol). This acylated-diterpenoid as well as pseudoalkaloid compound is an anti-microtubule agent and has been first isolated from Yew tree bark [11].

\footnotetext{
${ }^{*}$ Corresponding author: Gopinath Rana

Cellular and Molecular Therapeutics Laboratory, Venkatesh Natural Extract Pvt. Ltd., Chhindwara, Madhya Pradesh, India.
} 
In India, Ashwagandha (Withania somnifera L. Dunal) is treated as a good medicinal plant and also known as 'Indian ginseng'. Several scientific papers have been reported that Ashwagandha Extract can enhance anti-cancer potentiality of any anti-cancer drug. In this experimental study, a new anti-proliferative agent has been screened and purified by High Performance Liquid Chromatography (HPLC). Finally, chemical characterization has also been carried out by UV, FT-IR, LC/MS and ${ }^{1} \mathrm{H}-\mathrm{NMR}$ analysis. Anti-tumorigenic activity of the isolated and purified drug has been carried out by MTT Assay with different cell-lines (HeLa, KB and HT cell-lines) and way of mechanism has been confirmed by Western blot technique.

\section{Material and methods}

\subsection{Plant collection}

In this experimental study, Ashwagandha (W. somnifera L. Dunal) whole plants were harvested from Nimaj, Madhya Pradesh, India (geographical coordinates of $26^{\circ} 8^{\prime} 58^{\prime \prime} \mathrm{N}$ to $74^{\circ} 0^{\prime} 0^{\prime \prime} \mathrm{E}$ and $315 \mathrm{~m}$ high from the mean sea level). Initially, whole plants were washed by using 1.0\%-sodium hypochlorite ( $\mathrm{NaOCl}$; Fisher Scientific, India) solution in water (v/v) and then plants were air dried. Finally, whole plants were dried under sunlight for one week.

\subsection{Preparation of whole plant extract}

Dried whole plants were grinded well using a grinder. 100 gm of whole plant powder was dipped in $1.0 \mathrm{~L}$ methanol (HPLC grade; Fisher Scientific; India) and left the mixture for soaking for whole night at room temperature. Then the mixture was refluxed for $4 \mathrm{hr}$ and filtered. The process had been repeated for three times for complete extraction and combined all extracted solution. The total solution was evaporated to dryness under vacuum at $50^{\circ} \mathrm{C}$ and finally the pest was completely dried at $80^{\circ} \mathrm{C}$. After complete drying the compound had been cooled down and powdered.

\subsection{Screening of new compound}

$50 \mathrm{mg}$ of crushed product was dissolved in methanol (HPLC grade; Fisher Scientific; India) and filtered through $0.45 \mu \mathrm{m}$ membrane filter (HIMEDIA; India). The methanol extract was then subjected to a HPLC (High Performance Liquid Chromatography, SHIMADZU; Japan) fitted with a C18-column and Mass Spectrophotometer (Thermo Fischer; India) and eluted with mobile phase containing methanol $\left(\mathrm{CH}_{3} \mathrm{OH}\right.$; HPLC grade, Fisher Scientific, India) and water in a ratio of 7:3 (v/v) [12]. The presence of new compound was checked (throughout the machine database and also from different scientific literatures) in $20 \mu \mathrm{l}$ extract and a compound with new molecular weight was identified as well as chromatographically purified.

\subsection{Chemical characterization}

The purified phytochemical was subjected to structural determination based on UV, IR, ${ }^{1} \mathrm{H}-\mathrm{NMR}$, and mass spectroscopy (LC/MS). The UV spectrum was recorded on a Shimadzu, UV-1800, spectrophotometer. IR spectrum was recorded on a Shimadzu, IR-408, spectrometer. ${ }^{1} \mathrm{H}-\mathrm{NMR}$ spectra were recorded on Bruker, AV- 300FT, NMR machine at $300 \mathrm{MHz}$ and chemical shifts were recorded in $\delta$ - units with TMS as internal standard [13].

\subsection{Anti- proliferativity assay of the isolated drug}

HT-29, KB and HeLa cells were separately seeded in 96 -well plate $\left(1 \times 10^{5}\right.$ cells/well), and incubated with different concentration of purified drug (phytogent) dissolved in ethanol, for $24 \mathrm{hr}$. Then, $100 \mathrm{uL} \mathrm{of} 2 \mathrm{mg} / \mathrm{mL}$ MTT reagent was added into each well and incubation continued for $3 \mathrm{hr}$. After $3 \mathrm{hr}$, excess MTT was washed out with sterile PBS and 100 $\mu \mathrm{L}$ of DMSO was added to solubilise the blue formazan crystals trapped inside the cells. The absorbance was measured at $570 \mathrm{~nm}$ with a microplate reader. The absorbance values were used to calculate the viability of HT-29 cells compared to the control group (in percentage).

The monolayer cells were detached with trypsin ethylene-diamine-tetra-acetic acid (EDTA, 1X) to make single cell suspensions and viable cells were counted using a haemocytometer and diluted with medium containing $10 \%$-FBS to give final density of $\left(1 \times 10^{5}\right)$ cells $/ \mathrm{mL}$. $100 \mu \mathrm{l}$ per well of cell suspension were seeded in to 96 -well plates at plating density of 10,000 cells/well and incubated to allow for cell attachment at $37{ }^{\circ} \mathrm{C}, 5 \%-\mathrm{CO}_{2}, 95 \%$ air and $100 \%$ relative humidity. After $24 \mathrm{hr}$, the cells were treated with serial concentration of the test samples. Aliquots of $200 \mu \mathrm{l}$ of these different sample dilutions were added to the appropriate wells already containing $200 \mu \mathrm{l}$ of medium, resulted the required final sample concentrations $(0.0,1.56,3.125,6.25,12.5,25.0,50.0 \mu \mathrm{g} / 200 \mu \mathrm{l})$. Following treatment with purified drug, the plates were incubated for an additional $24 \mathrm{~h}$ at $37 \stackrel{\circ}{\circ} \mathrm{C}, 5 \%-\mathrm{CO}_{2}, 95 \%$ air and $100 \%$ relative humidity. The medium without samples were served as negative control and medium treated with Adriamycin positive control, triplicate was maintained for all concentrations. 
HT-29, KB and HeLa cells were separately and respectively treated with the isolated drug for $48 \mathrm{~h}$, then harvested and conducted to flowcytometry analysis (Becton Dickinson, USA). For cell cycle analysis, after the indicated treatments, different cells were analysed by flow cytometer (FACScan) in the presence of PI buffer with RNase (SRL, India).

\subsection{Western-blot analysis}

A pellet containing $1 \times 10^{5}$ cells was solubilised by incubation in ice-cold lysis buffer [150 mM NaCl, $50 \mathrm{mM} \mathrm{Tris} \mathrm{(pH} \mathrm{7.4),}$ 5 mM EDTA, $0.1 \%$ NP40, 0.5\% sodium deoxycholate, $0.1 \%$ SDS, complete protease inhibitor aliquot] for 10 min. Sample loading buffer was added and the mixture was boiled for $5 \mathrm{~min}$. Proteins were separated by electrophoresis in $12 \%$ polyacrylamide gels or 4-12\% Bis-Tris precast gels and transferred to PVDF membranes (Millipore, Molsheim, France).

\subsection{Reactive oxygen species (ROS) assay}

ROS levels were tested using 2', 7' - dichlorofluorescein diacetate [DCFH-DA] using kits. HT-29, KB and HeLa cells were exposed to isolated drug for $24 \mathrm{~h}$ and then washed with phosphate-buffered saline (PBS) for three times. After that, cells were treated with DCFH-DA for $30 \mathrm{~min}$ and viewed under a fluorescence microscope with excitation at $490 \mathrm{~nm}$ and emission at $520 \mathrm{~nm}$ (BX51, Olympus, PA) [14].

For quantitative assay, cells were homogenised in PBS with a PT 10/35 Polytron system (Brinkman, Westbury, NY) after perfusion. Homogenates were stained with DCFH-DA from the Tissue ROS Assay kit (Merck, Germany). Samples were placed in 96 - well plates, and the rate of formation of highly fluorescent DCF was measured after 30 min incubation at $37^{\circ} \mathrm{C}$ with an excitation frequency $488 \mathrm{~nm}$ and emission frequency of $520 \mathrm{~nm}$.

\section{Results and discussion}

\subsection{Purified compound by column chromatography and assay by HPLC}

New compound containing fractions were pooled, concentrated and again run through a separate C18 - column with the methanol as the mobile phase. Purified product was collected and crystallized. Purified compound again verified by HPLC and it had been found as $98.321 \%$ pure with a retention time $4.067 \mathrm{~min}$ (Figure1a).

\subsection{Chemical characterization of the purified drug}

$10 \mathrm{mg}$ compound was dissolved in $10 \mathrm{ml}$ methanol (HPLC grade) and scanned against a blank (methanol; HPLC grade). $\lambda_{\max }$ of the purified compound had been found as $212.0 \mathrm{~nm}$ (Figure 1b). IR spectra and corresponding peaks identification are shown in Figure 1c. Paclitaxel has the empirical formula $\mathrm{C}_{47} \mathrm{H}_{51} \mathrm{NO}_{14}$, corresponding to a molecular weight of $853.9 \mathrm{~g} / \mathrm{mol}$. Here we have got 854.60 with some of its fragments (Figure $1 \mathrm{~d}$ ). The peaks corresponding to Paclitaxel, exhibited mass-to-charge $(\mathrm{m} / \mathrm{z})$ ratios corresponding to the molecular ions of standard Paclitaxel (854.90) confirming the purified product is Taxol purified from Ashwagandha whole plant extract.

${ }^{1} \mathrm{H}$-NMR spectra has been recorded at $23{ }^{\circ} \mathrm{C}$ in $\mathrm{CDCl}_{3}$ solvent. Almost all of the signals are well resolved and are distributed in the region from 1.0 to $8.1 \mathrm{ppm}$. The strong three-proton signals caused by the methyl and acetate groups lie in the region between 1.0 and $2.3 \mathrm{ppm}$, together with multiplets caused by certain methylene groups. Most of the protons in the taxane skeleton and the side-chain are observed in the region between 2.5 and 7.0 ppm, and the aromatic proton signals caused by the $\mathrm{C}-2$ benzoate, $\mathrm{C}-3^{\prime}$ phenyl and $\mathrm{C}-3^{\prime}$ benzamide groups appear between 7.0 and 8.1 ppm. The characteristic chemical shifts of Taxol are shown in Figure 1e. 
GSC Biological and Pharmaceutical Sciences, 2020, 13(01), 045-053

$\mathrm{mV}$

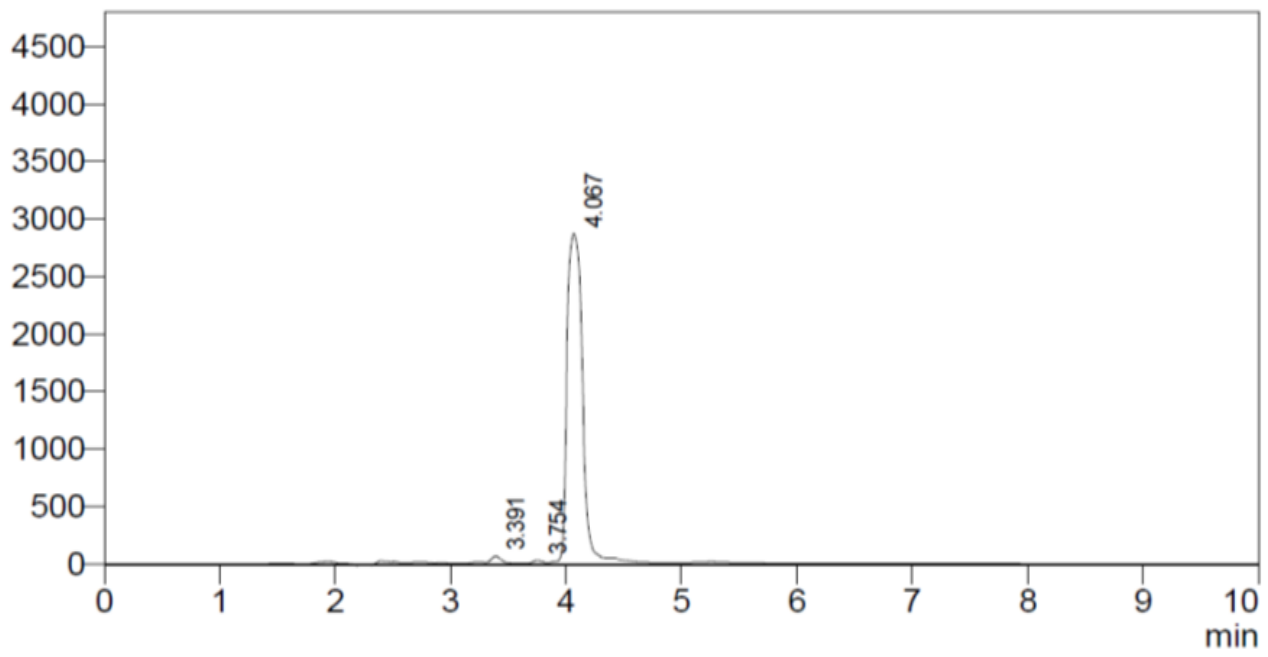

(a)

PDA Ch1 227nm
\begin{tabular}{|r|r|r|r|r|}
\hline Peak\# & Ret. Time & \multicolumn{1}{|c|}{ Area } & Height & Area $\%$ \\
\hline 1 & 3.391 & 314957 & 60708 & 1.212 \\
\hline 2 & 3.754 & 121180 & 25350 & 0.466 \\
\hline 3 & 4.067 & 25545565 & 2848451 & 98.321 \\
\hline Total & & 25981702 & 2934509 & 100.000 \\
\hline
\end{tabular}

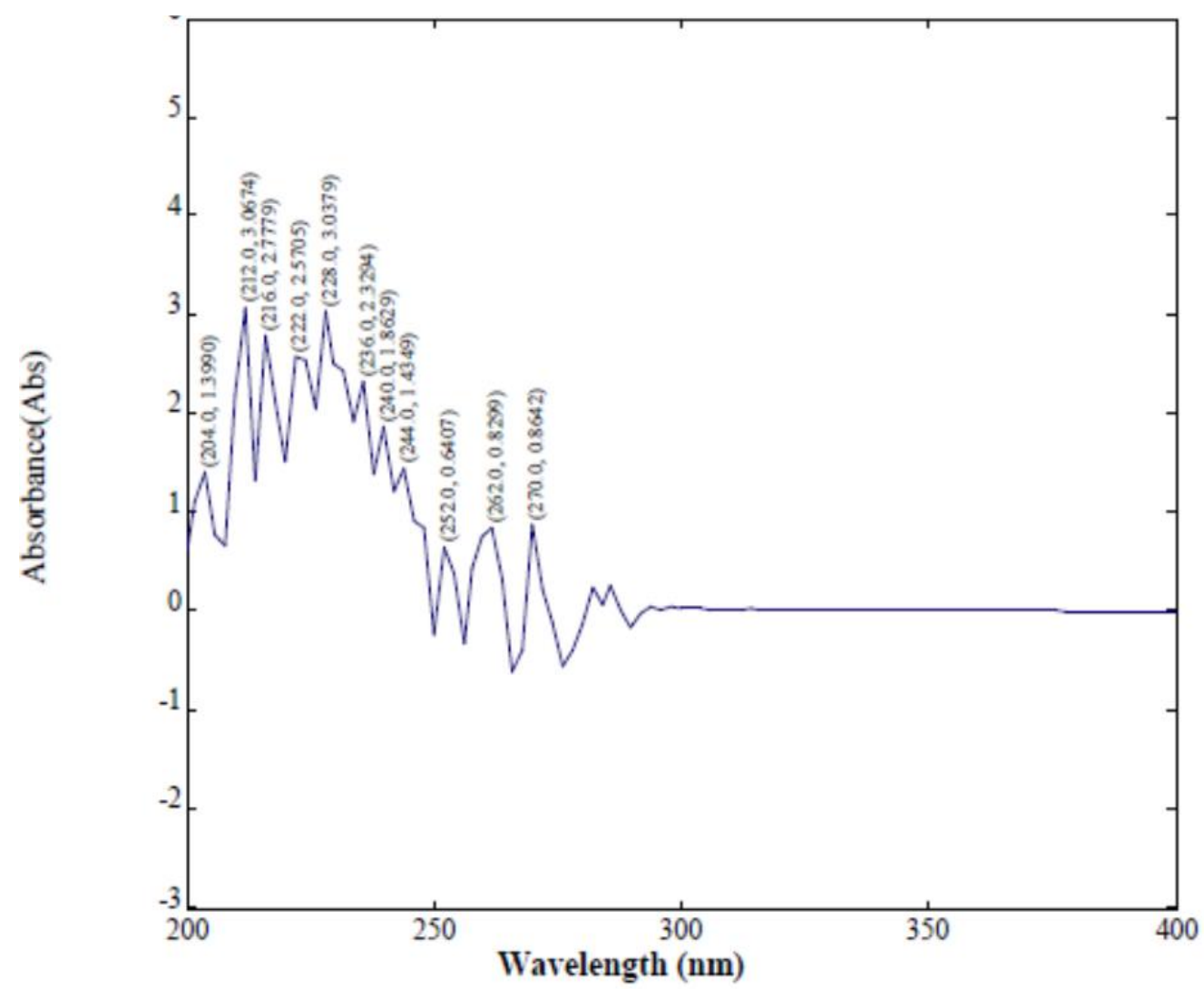

(b) 
GSC Biological and Pharmaceutical Sciences, 2020, 13(01), 045-053

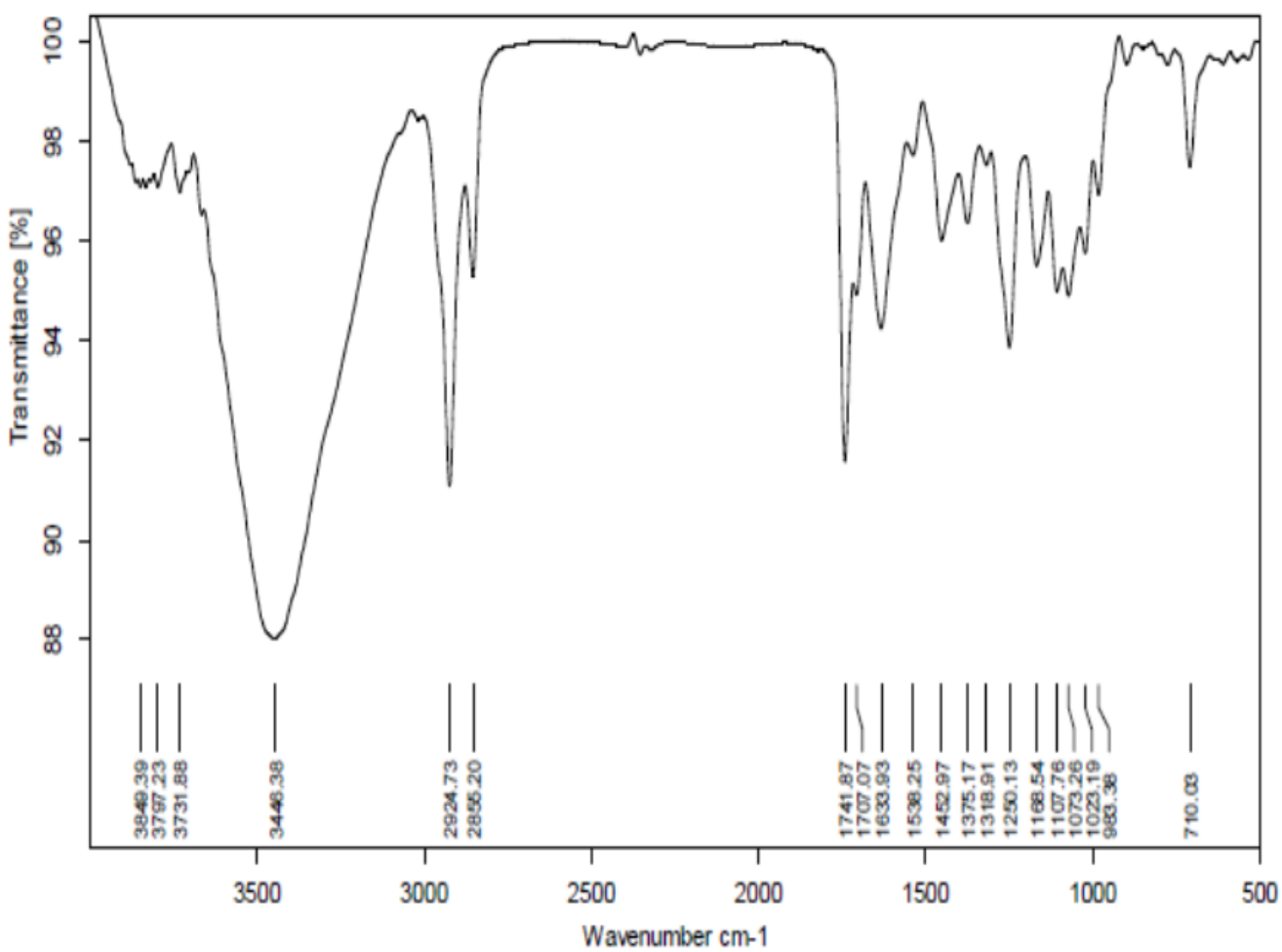

(c)

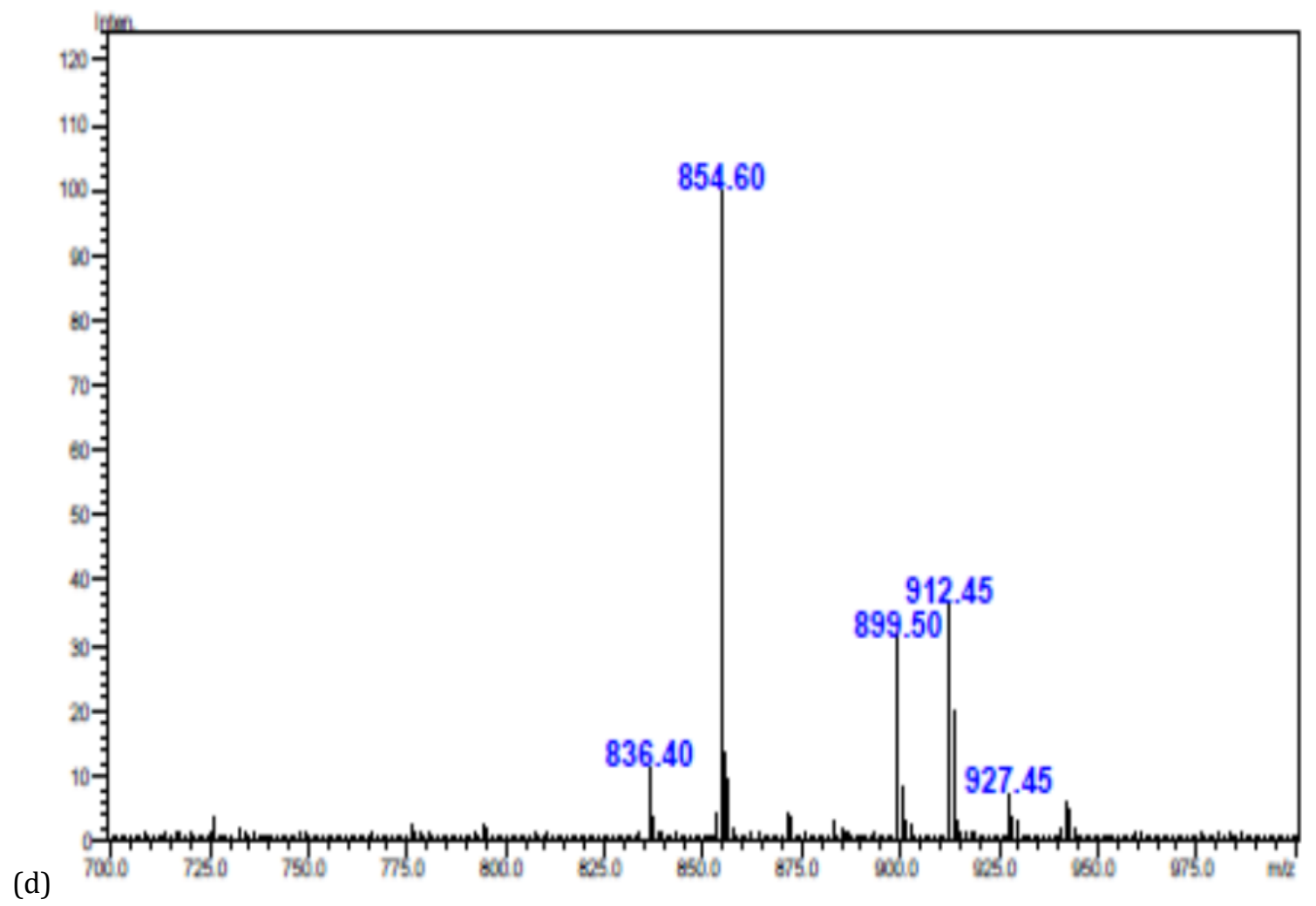




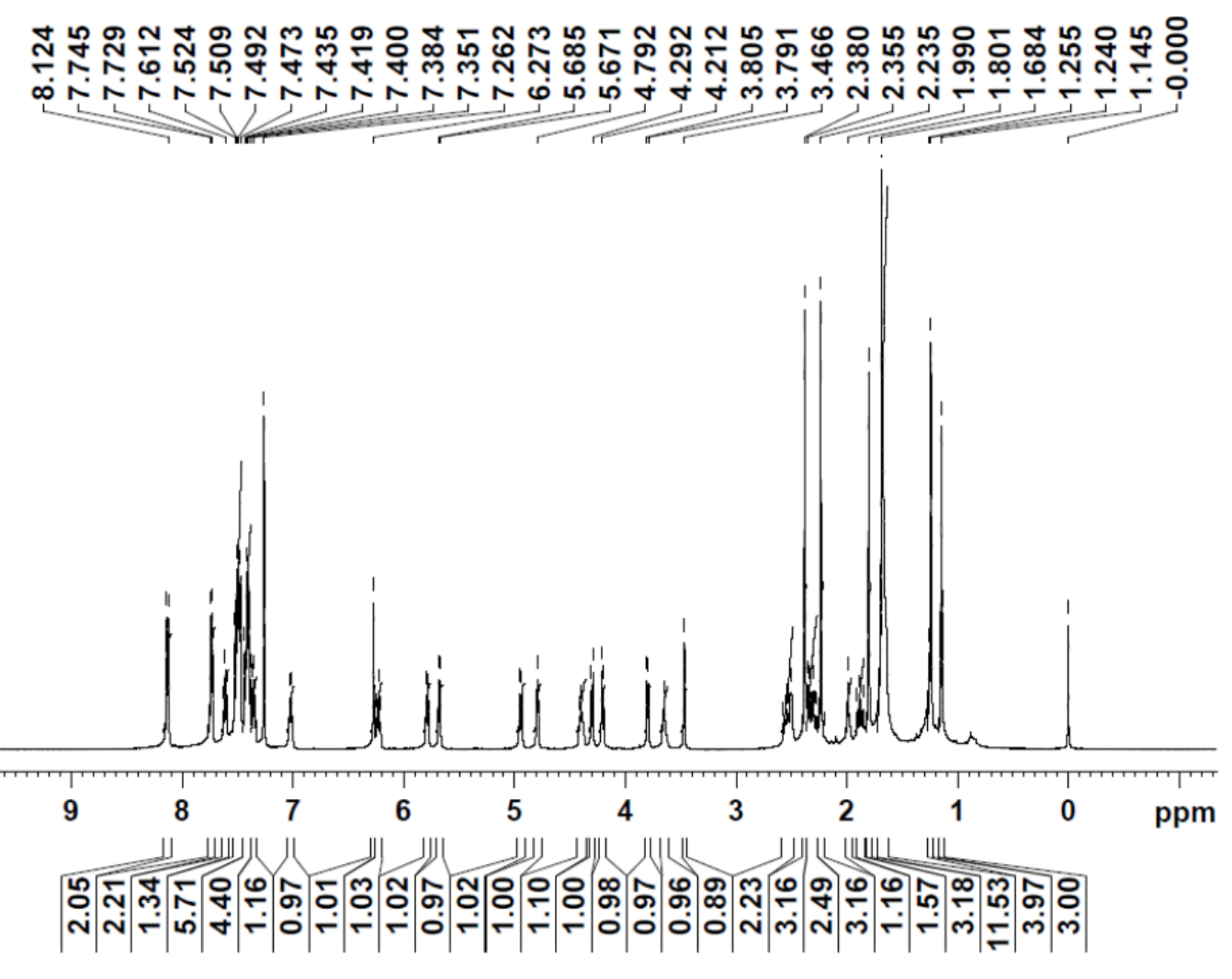

Figure 1 Chemical characterization of the purified phytochemical: (a) High Performance Liquid Chromatogram with PDA of the purified compound from Ashwagandha (Withania somnifera L. Dunal), (b) UV - spectra of the purified compound, (c) IR spectra of purified compound isolated from Ashwagandha, (d) Liquid Chromatography-Mass Spectra (LC/MS) of isolated/purified Taxol from Ashwagandha \& (e) ${ }^{1} \mathrm{H}-\mathrm{NMR}$ spectra of the purified Taxol from Ashwagandha.

\subsection{ROS levels}

ROS is a key factor for cell cycle phase distribution and different intracellular metabolic activities. Cellular ROS levels were analysed by flowcytometry using DCFH-DA containing assay kits. For each sample, the mean fluorescence intensity (percentage of MFI) was measured. At initial phase, cellular ROS gradually increased and reached to a maximum of about 7 times more than control (untreated) cells. Thereafter, the MFI declined and become stable. But the ROS level remains higher than the control cells. Same results were observed during fluorescent microscopic study.

\subsection{MTT Assay}

MTT assay results showed that purified drug has a concentration dependent effect on all types' of cell taken for this experimental assay. The concentration of compound correlated inversely with cell viability of the cells indicating that increasing concentration of 'purified compound/drug' decreased the cell viability of both cells (Figure 2, 3 and 4). The results indicate that the purified compound has potential anti-cancer properties against all three cancer cell lines. 

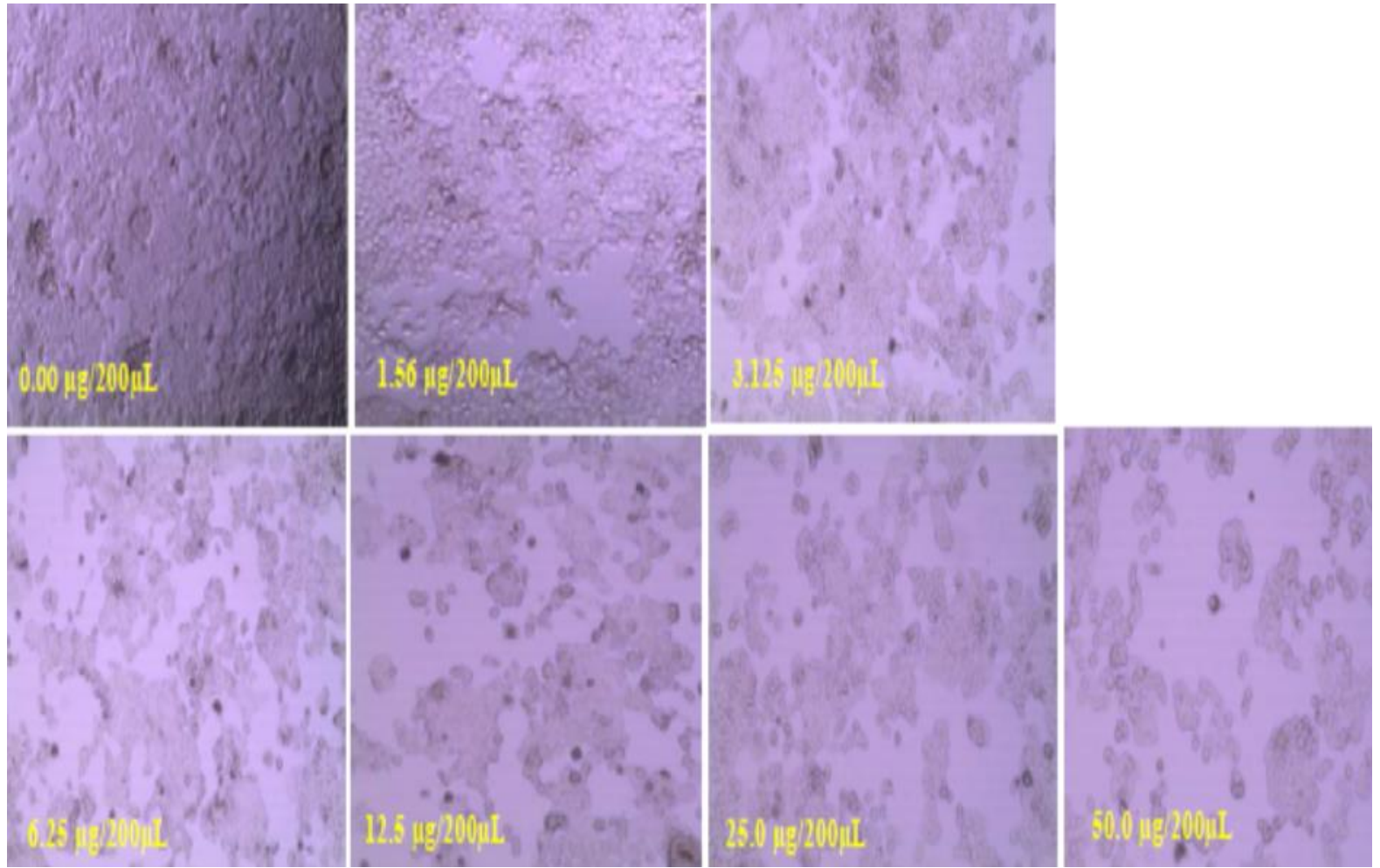

Figure 2 HT-29 cell arrests by purified Paclitaxel at different concentration.
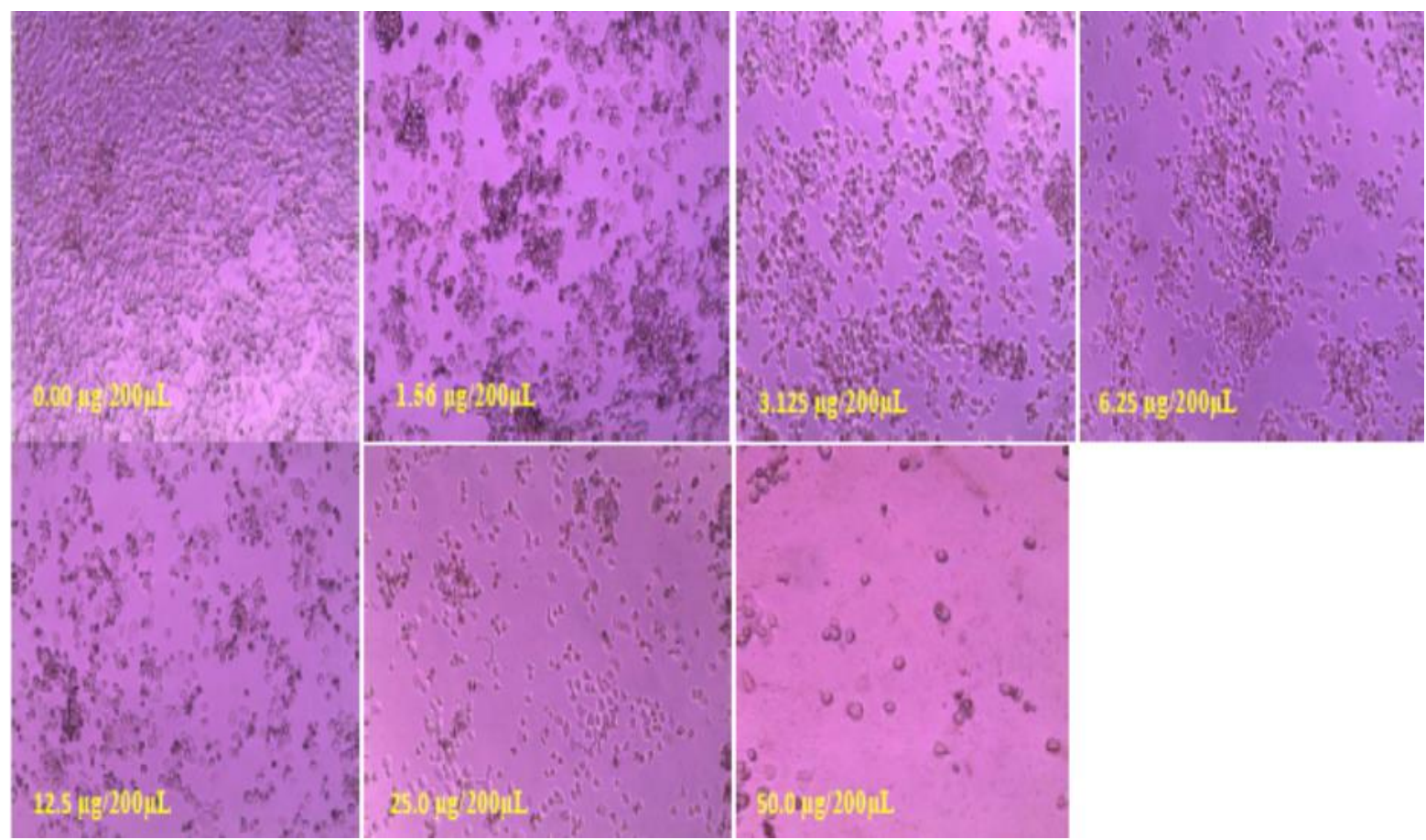

Figure $3 \mathrm{~KB}$ cell arrest by 'Ashwagandha whole plants extract' at different concentration. 

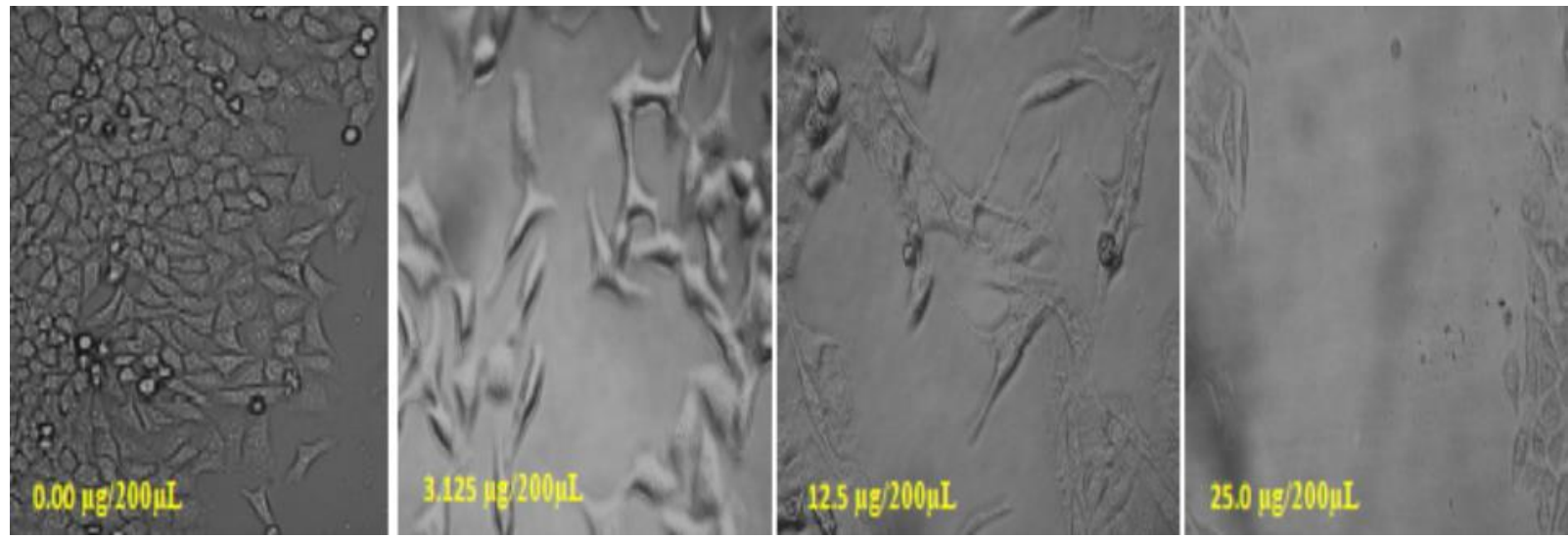

Figure 4 HeLa cell arrest by 'Ashwagandha whole plants extract' at different concentration.

\section{Conclusion}

Based on MTT assay results, DAPI staining was conducted to investigate the phytogent induced changes in cell structures. Cells were incubated with the extracted compound and morphological alterations and cell arrest phenomena were confirmed by inverted florescence microscope (Oympus, PA). HeLa cells were again treated with Taxol (0-0.5 $\mathrm{mg} / \mathrm{mL}$ ) for $24 \mathrm{hr}$, harvested, and counted. Cell adhesion was determined after $1.5 \mathrm{hr}$ of incubation at $37^{\circ} \mathrm{C}$. Cell migration of HeLa cells treated with the purified compound (0-0.5 mg/mL) was assessed in Transwell chambers in the DMEM medium containing $10 \%$ FBS.

HeLa $\left(1 \times 10^{5}\right)$ cells $/ \mathrm{ml}$ treated with $0.00,3.125,12.50$ and $25.0 \mathrm{mg} / \mathrm{mL}$ of Taxol for $24 \mathrm{hr}$. Cells were lysed and western blotted using PRAP, Cleaved PRAP, Caspase -3, Cleaved Caspase -3, Bcl-2 (B-cell lymphoma 2), Bax (Bcl-2-associated X protein), p53 and MDM2 (Santa Cruz Biotechnology). The level of expression of a panel of proteins involved in these pathways in HeLa cells. It has been observed a dose-dependent increase in the expression of Cleaved-Poly (ADP ribose) Polymerase (PARP) and Caspase-3, as well as Bax, with a concomitant dose-dependent decrease in Bcl-2. It has been further evaluated the regulatory effects of drug on p53, and found activated p53 tumor suppressor (a transcription factor), with an accompanying down regulation in murine double minute-2 (MDM2, cellular regulator) expression and increased cleavage of PARP and Caspases-3 (Figure 5). These findings are indicative of apoptosis and/or antiproliferative and cell cycle inhibitory effects. From these it can conclude that Taxol may exert it's in vitro effects through the ROS-associated, and p53-MDM2-related cell proliferation, apoptosis and cell cycle progression. Cell cycle study has revealed that the isolated-drug has good cell arrest ability and an accumulation of cell population has been found in G0/G1-phase after the drug treatment.

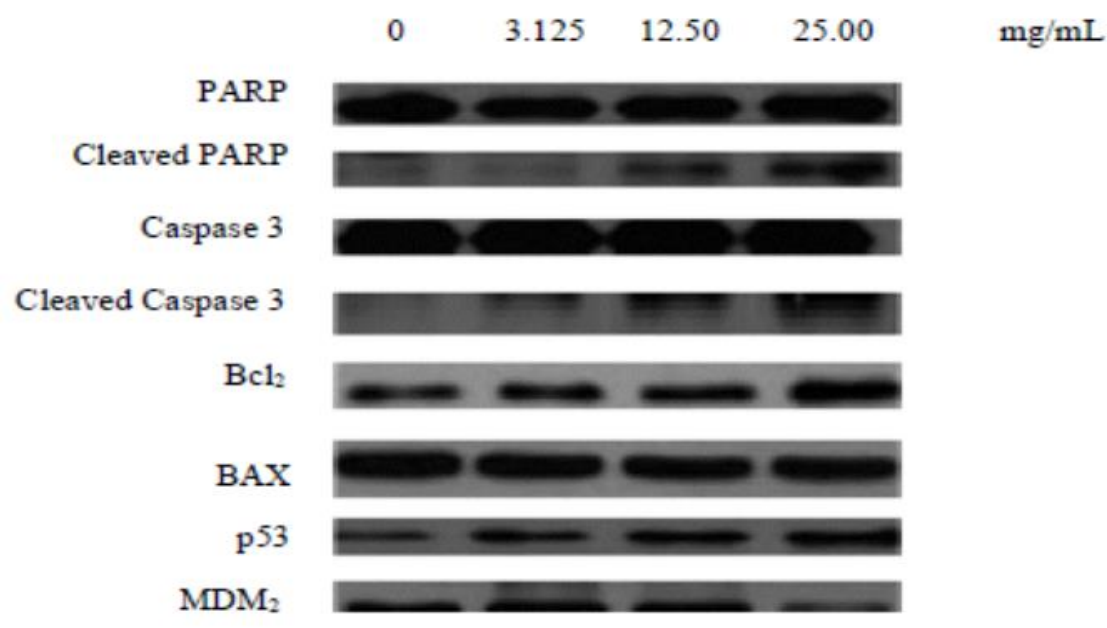

Figure 5 Western blot of different proteins, involve in cervical cancer during treatment after 24 hours. 
Thus in future, Ashwagandha can be used either as a source of Taxol or directly as a next generation anti-neoplastic agent. This may be an important search in phyto-chemistry for purification of Taxol and cancer treatment.

\section{Compliance with ethical standards}

\section{Acknowledgments}

All the Laboratory members of "Venkatesh Food Industries" are acknowledged for their help, co=operations and inspiration during conducting this project.

\section{Disclosure of conflict of interest}

Authors have no conflict of interest in publishing this article.

\section{References}

[1] Henley AB, Yang L, Chuang KL, Sahuri-Arisoylu M, Wu LH, Bligh SWA, Bell JD. Withania somnifera root extract enhances chemotherapy through 'Priming'. PLoS ONE. 2017; 12: e0170917.

[2] Uddin Q, Samiulla L, Singh VK, Jamil SS. Phytochemical and pharmacological profile of Withania somnifera Dunal: A review. J Appl Pharmaceut Sci. 2012; 2: 170-175.

[3] Xu Y, Gao S, Bunting DP, Gunatilaka AAL. Unusual withanolides from aeroponically grown Withania somnifera. Phytochem. 2011; 72: 518-522.

[4] Wadhwa R, Singh R, Gao R, Shah N, Widodo N, Nakamoto T, Ishida Y, Terao K, Kaul SC. Water extract of Ashwagandha leaves has anticancer activity: Identification of an active component and its mechanism of action. PLoS ONE. 2013; 8: e77189.

[5] Lewis CW, Jin Z, Macdonald D, Wei W, Qian XJ, Choi WS, He R, Sun X, Chan G. Prolonged mitotic arrest induced by Wee1 inhibition sensitizes breast cancer cells to Paclitaxel. Oncotarget. 2017; 1-18.

[6] Komakech R, Kang Y, Lee J-H, Omujal F. A review of the potential of phytochemicals from Prunus Africana (Hook f.) Kalkmam stem bark for chemopreventive and chemotherapy of prostate cancer. Evidence-Based Complement. Alternat Med. 2017; Article ID 3014019.

[7] Singh AN, Baruah MM, Sharma N. Structure Based docking studies towards exploring potential anti-androgen activity of selected phytochemicals against Prostate Cancer. Sci Rep. 2017; 7: 1955.

[8] Eldahshan OA. Fighting cancer by phytochemicals. Int J Pharmacog Chinese Med. 2017; 1: 1-2.

[9] Meybodi NM, Mortazavian AM, Monfared AB, Sohrabvandi S, Meybodi FA. Phytochemicals in cancer prevention: A review of the evidence. Iran J Cancer Prev. 2017; 10: e7219.

[10] Yin S-Y, Yang N-S, Lin T-J. Phytochemicals approach for developing cancer immunotherapeutics. Front Pharmacol. 2017; 8: 386.

[11] Hire RR, Srivastava S, Davis MB, Konreddy AK, Panda D. Antiproliferative activity of Crocin involves targeting of microtubules in breast cancer cells. Sci Rep. 2017; 7: 44984.

[12] Rana G, Mandal T, Mandal NK, Sakha D, Meikap BC. Calcite Solubilization by Bacteria: A Novel Method of Environment Pollution Control. Geomicrobiol J. 2015; 32: 846-852.

[13] Rana G. Inhibition efficiency of a newly isolated flavonoid compound from Vitex negundo L. leaves against cattleendosymbiont Setaria cervi: Phytomedicine for lymphatic filariasis. Paracite Epidemiol Control. 2018; 3: 88-95.

[14] Mansfield KD, Guzy RD, Pan Y, Young RM, Cash TP, Schumacker PT, Simon MC. Mitochondrial dysfunction resulting from loss of cytochrome c impairs cellular oxygen sensing and hypoxic HIF- $\alpha$ activation. Cell Metabolism. 2005; 1: 393-399. 